\title{
PHYTOREMEDIATION OF SOILS CONTAMINATED WITH USED LUBRICATING OILS USING SUNFLOWER
}

\author{
Sérgio Machado Corrêa \\ Rio de Janeiro State University-UERJ, Rio de Janeiro, Brazil
}

\begin{abstract}
Lubricating oil is one of the most important derivatives from petrol industry. However its life cycle finished with the generation of the used oil, harmful to the environment and must be suitable disposed. A Brazilian law authorized the use of $30 \%$ of re-refined lubricating oil with the new oil. This market leads to the establishment of several new industries which use small and medium trucks to collect used oil at gas stations where consumers change the lubricant oil. On the last years an intense flux of these trucks can be observed at the main road of Brazil, which connects Rio de Janeiro and São Paulo, the two biggest cities of our country. This scenario can lead to possible accidents and oil spills. This paper relates the use of sunflower to remediate soils collect at the margin of this important road. It was tested soils contaminated with 2, 4, and $6 \%$. The soils were extracted with Soxhlet extraction using cyclohexane and analyzed by gas chromatography with flame ionization detection. The first three months of the experiments indicated a phytoremediation of 86,82 , and $65 \%$ for the soils contaminated with 2,4 , and $6 \%$, respectively.
\end{abstract}

\section{KEYWORDS}

Oil; phytoremediation; chromatography; contaminated soils.

\section{INTRODUCTION}

Lubricating oil is one of the most important products from petrol industry, by its value, several uses, technical requirements, and developments in its fabrication to follow the advances in engines. However, its life cycle ends with the generation of a residue, very harmful to the environment otherwise not suitable dispose, with metals and degraded organic and inorganic compounds in its composition. Data from the distributors companies of these products indicated that lubricating oil market is greater than one million of cubic meters per year in Brazil.It is estimated that $50 \%$ of the used lubricating oils can be collected to be reprocessed, once some types of this product can not be regenerated, as the soluble oils and others that is burned together with the fuels. As reported by the distributors these oil collection is near $50 \%$ of the available used oil at the great cities as the metropolitan area of Rio de Janeiro and São Paulo. This quantity lead to a difficult management of the collection process, since that this collection is made by small companies, and is very difficult to follow.

In 1993, with the purpose to minimize the inadequate discharge of the used lubricating oil, the National Environment Council (CONAMA) enact a law (CONAMA 09/93) that establishes basic rules to the dispose of the used or contaminated oils, to avoid the environment impacts. 
This resolution was upgraded by the resolution CONAMA 464/2007, that still in validity. This resolution establish that the disposition of these oils must done by recycling using the rerefining process, to remove contaminants, degradation products, unusable additives, conferring to the new products basic properties to be used as raw material to be used as a new lubrication oil in a limit of $30 \%$ in volume. This resolution also instruct the collection and destination activities of the used of contaminated oils, establishing the responsibilities of the manufacturers, importers, resellers, and consumers of these products.

It is unquestionable that used lubrication oils, when unsuitable discharged may lead to harmful consequences to the environment. Despite this Brazilian law is considered actual and more restrictive than similar of developed countries as France and Italy, some factors difficult the complete execution.

The used lubricating oils contain deterioration products as oxygenated hydrocarbons (organic acids and carbonyls compounds), polynuclear aromatic hydrocarbons (PAH), and resinous substances. Other inorganic compounds are also present as additives to adjust the oils properties as viscosity, density, superficial tension, detergent proprieties, among several others. Others compounds may be present as metals removed from the structural parts of engines, sealants, particulates and water. This scenario leads to a multi-contamination event that must be studied in detail. A recent search in the literature found no research in this area using the keywords "lubricating oil" and "phytoremediation".

\section{EXPERIMENTAL PHASE}

The vegetable used to remediate soils contaminated with lubricating oils was the Helianthus annus (sunflower). The soil tested was collected at five different places $(20 \mathrm{~km}$ from each one) at the margin of the Presidente Dutra Highway, the most important highway in Brazil, which connect São Paulo do Rio de Janeiro. The collected soils were mixed and used in all experiments, and were classified as lato soils. The used lubricating oil was collect from the engines from 3 different automobiles and mixed.

The experiments were conducted in an open place, with a roof to protect from rain. Eight experiments were done, in triplicate, totalizing 24 experiments, as follow:

Experiment 1, 2, and 3: only soil.

Experiment 4, 5, and 6: soil with sunflower.

Experiment 7, 8, and 9: soil with $2 \%$ of used lubricating oil.

Experiment 10, 11, and 12: soil with $4 \%$ of used lubricating oil.

Experiment 13, 14, and 15: soil with $6 \%$ of used lubricating oil.

Experiment 16, 17, and 18: soil with $2 \%$ of used lubricating oil and sunflower.

Experiment 19, 20, and 21: soil with $4 \%$ of used lubricating oil and sunflower.

Experiment 22, 23, and 24: soil with $6 \%$ of used lubricating oil and sunflower.

The experiments were conducted during three months at Resende, a city located at the south of the Rio de Janeiro State $\left(22^{\circ} 29^{\prime} \mathrm{S}\right.$ and $44^{\circ} 28^{\prime} \mathrm{W}$ Gr) at $440 \mathrm{~m}$ of altitude. The region 
climate is dry tropical with $1200 \mathrm{~mm}$ of precipitation concentrated during October to March. The mean temperature of the experiment was $24,7^{\circ} \mathrm{C}$ and the humidity of $71 \%$.

For each month, portions of $10 \mathrm{~g}$ of contaminated soil were removed to evaluate the process. The soil samples were put inside filter paper folders and the extraction were done using 200 $\mathrm{mL}$ of cyclohexane in a Soxhlet extractor, during 6 hours. After the extraction the samples were concentrated in an evaporative device to a volume of $10 \mathrm{~mL}$.

The chemical analyses were carried using a gas chromatography with a flame ionization detector (FID) (Agilent GC 6890). No identification or quantification of the contaminants was done. The evaluation of the phytoremediation process was done comparing the total area obtained in the respective chromatograms of each experiment.

A capillary column (DB-1. $30 \mathrm{~m} \times 0.25 \mathrm{~mm} \times 0.25 \mu \mathrm{m}$ ) was used to separate the species and Helium was used as carrier gas at a flow rate of $1.5 \mathrm{~mL} \mathrm{~min}^{-1}$. The injection temperature was $300^{\circ} \mathrm{C}$ in splitless condition with $1.0 \mu \mathrm{L}$ of injection volume. The oven temperature starts at $60^{\circ} \mathrm{C}$ and programmed to $320^{\circ} \mathrm{C}$ at $10^{\circ} \mathrm{C} \mathrm{min}^{-1}$, and the FID was set to $340^{\circ} \mathrm{C}$.

The soil samples were collected 30,60, and 90 days after the beginning of the experiments. Sunflower plants were inserted into contaminated soils when they were with $8-10 \mathrm{~cm}$ of height.

\section{RESULTS AND DISCUSSION}

The experiments done only with soil were to investigate the possible presence of previous contaminants. The experiments with soil and used lubricating oil without sunflower were done to evaluate the loss of contaminants by volatilization.

The results indicated a very low remediation in the first month, basically by the adaptation of the vegetable in the contaminated soil. After 60 days some remediation can be visualized in the range of $30 \%$, but in 90 days the remediation is better than $60 \%$, as can be seen at Figure 1.

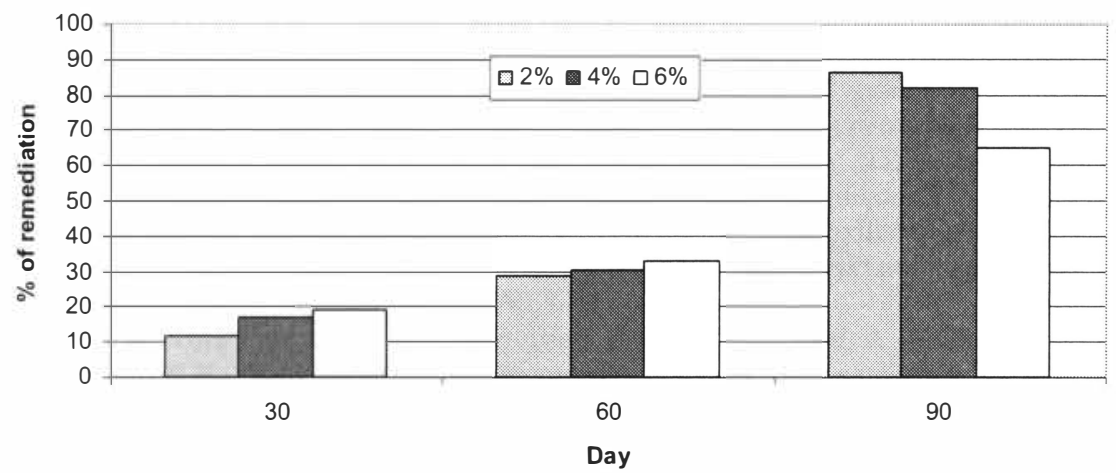

Figure 1. Results for the sunflower remediation of soil contaminated with 2, 4, and $6 \%$ of lubricating oil based on areas obtained in the chromatogram. 
At the first 60 days of the experiment it can be observed a greater remediation of the soil contaminated with higher oil content. This can be an indicative of a strong volatilization process promoted by the sunflower. After 90 days of the experiment the best results were obtained by the remediation of the soil contaminated with $2 \%$ of lubricating oil. The sunflower of the experiment with $6 \%$ of oil after 90 days, and in a minor extent the $4 \%$, were affected by these oil contents, and some damages were observed in the leafs.

A secondary result obtained by this work indicated that the remediation process is more intense on the heavier compounds, by the observation of a more intense reduction of the chromatograms area of the peaks obtained at the end of the chromatogram. It is interesting to observe that the results presented at Figure 1 are only a mean reduction of near 120 chromatogram peaks. Some compounds peak area did not experiment a reduction and some others increase, possible by the inter-conversions of one substance to other. Also some compounds experimented $100 \%$ of reduction. These individual results are now being investigated and will be published soon.

\section{CONCLUSIONS}

This work is an initial research to investigate the possible contamination of used lubricating oil of soils from highways margins. A more careful set of experiments need to be done, as oil and soil characterization, and the sunflower or other specie must be follow in all its parts, as roots and leafs. But these primary results indicated a good potential to use the Phytoremediation technique. A more detailed study must be done to evaluate the contamination limit. Studies are also necessary to investigate the remediation of inorganic compounds, mainly the metals associated with the used oil. These metals probably are being remediated by phytoaccumulating process.

\section{REFERENCES}

[1] Huang, X-D.; El-Alawi, Y.; Gurska, J.; Glick, B.R.; Greenberg, B.M. (2005) A multiprocess phytoremediation system for decontamination of persistent total petroleum hydrocarbons (HTPs) from soils. Microchemical Journal 81(2005) 139-147.

[2] Hutchinson, S.L.; Schwab, A.P. and Banks, M.K. (2003). Biodegradation of petroleum hydrocarbons in the rhizosphere. In: Mccutcheon, S.C. \& Schonoor, J.L. (2003). Phytoremediation: Transformation and Control of Contaminants. John Wiley \& Sons (Eds.). New Jersey, p. 987 p

[3] Mccutcheon, S.C. \& Schonoor, J.L. (2003). Phytoremediation: Transformation and Control of Contaminants. John Wiley \& Sons (Eds.). New Jersey, p. 987p

[4] Merkl, N.; Schultze-Kraft, R.; Infante, C. Phytoremediation in the tropics - The effect of Crude Oil on the Growth of Tropical Plants. Bioremediation Journal, v.8, p.177-184, $2004 b$

[5] Morikawa, H. \& Erkin, Ö.C. (2003) Basic processes in phytoremediation and some applications to air pollution control. Chemosphere, V 52(9):1553-1558.

[6] USEPA - UNITED STATE ENVIRONMENTAL PROTECTION AGENCY, (2000). Introduction to Phytoremediation. Cincinnati- Ohio, (EPA/600/R-99/107). Disponivel em:<http:www.clu-in.org/download/remed/introphyto.pdf $>$. Acesso em: Novembro de 2005 .

[7] White, JR, P.M. Wolf, D.C., Thoma, G.J.; Reynolds, C.M. (2005). Phytoremediation of Alkylated Polycylclic Aromatic Hydrocarbons in a Crude oil-Contaminated Soil. In: Water, Air, and Soil Pollution (2006) 169: 207-220. 